\title{
Surveillance \& Society \\ Dis-ease Surveillance: How Might Surveillance Studies Address COVID-19?
}

Editorial

\section{Martin French}

Concordia University, Canada martin.french@,concordia.ca

\section{Torin Monahan}

University of North Carolina at Chapel Hill, USA

torin.monahan@unc.edu

\begin{abstract}
We are currently in the midst of a global pandemic with the spread of Coronavirus Disease 2019 (COVID-19). While we do not know how this situation will unfold or resolve, we do have insight into how it fits within existing patterns and relations, particularly those pertaining to sociocultural constructions of (in)security, vulnerability, and risk. We can see evidence of surveillance dynamics at play with how bodies and pathogens are being measured, tracked, predicted, and regulated. We can grasp how threat is being racialized, how and why institutions are flailing, and how social media might be fueling social divisions. There is, in other words, a lot that our scholarly community could add to the conversation. In this rapid-response editorial, we provide an introduction to the framing devices of disease surveillance and discuss how a surveillance studies orientation could help us think critically about the present crisis and its possible aftermath.
\end{abstract}

\section{Introduction}

There is nothing quite like a pandemic to provoke profound questions about one's health and mortality, the anthropocentric conceit underlying the shared fiction of national borders, and humanity's place in Planet Earth's natural history. Amidst the fear and anxiety now being sparked by global reactions to Coronavirus Disease 2019 (COVID-19), it seems pertinent to reflect on how surveillance studies might address not only the specter of emerging infectious disease, but also the entangled web of social relations that this specter feeds off of and helps to catalyze.

In this editorial, we provide a brief overview of epidemics, pandemics, and outbreaks as social problems in order to situate our thinking about COVID-19. We next consider the concept of disease surveillance, sketching two different genealogies: one developed by public health professionals and scholars and the other articulated within surveillance studies and the critical social sciences in response to this public health approach. In recognition of the fact that scholars in our field may be called upon to speak to issues raised by COVID-19 and other communicable diseases, we then briefly discuss how a surveillance studies orientation can help us think critically about such crises and responses to them.

\section{Epidemics, Pandemics, and Outbreaks}

Popular culture has furnished us with countless representations of the apocalyptic fallout stemming from uncontrolled communicable disease. For example, in the 1995 Wolfgang Petersen film, Outbreak-an adaptation of Richard Preston's The Hot Zone-Dustin Hoffman plays a US Army virologist given the harrowing task of tracking down the cause of a mysterious illness while his superiors attempt to suppress 
his findings. Merging disease-outbreak fiction with the zombie genre, Marc Foster's filmic adaptation of Max Brooks' World War Z features Brad Pitt in a similar race against time to develop a vaccine. Both films center on heroic protagonists and evoke images of "disease detectives" (Wald 2008) who are struggling against the odds to save humanity; neither film says much about conditions of stark inequality that threatened humanity in the first place. The larger social problems are instead sublimated through the figure of a deadly causal agent. As shallow as these representations are, they reflect commonplace and widespread beliefs, which are easily activated and reinforced by media coverage of public health events.

In the face of such representations, which under current conditions have the capacity to ignite fear and anxiety, how do we get to a deeper understanding of epidemics, pandemics, and outbreaks? Epidemics, the Oxford English Dictionary tells us, are widespread occurrences of infectious disease in a community at a particular time. Pandemics, inclusive of all the demos, suggest the prevalence of infectious disease on a large scale, something spread to whole countries or the whole world and usually signifying an epidemic that is beyond control. Outbreak connotes the temporality of these events, suggesting a "violent start of something unwelcome" (OED 1998: 1316). These terms may be said to make up part of a discourse or narrative that crystalizes webs of complex social relations into identifiable social problems (Wald 2008). They suggest an escalation of disease in populations and also "indicate the peculiar mobility of infectious agents, which transform the bodies of humans and other animals into vectors in order to move through space and across time" (French et al. 2018: 60). As epidemics, pandemics, and outbreaks become recognized as social problems, and as they subsume other social problems, critical analysts would want to attend to their cultural, symbolic, structural, and complex material dimensions. They would want, at a minimum, to keep track of how these terms contain and configure bodily vulnerability, stigmatization and marginalization, structural inequalities and violence, and disease construction and management (French et al. 2018).

COVID-19

With these dimensions in view, what can be said about COVID-19? First appearing as a cluster of pneumonia cases in December 2019 in Wuhan, Hubei, China, "with clinical presentations greatly resembling viral pneumonia," COVID-19-a "novel coronavirus" (Huang et al. 2020: 497) — was identified in "samples of bronchoalveolar lavage fluid (BALF) from a patient from Wuhan by scientists of the National Institute of Viral Disease Control and Prevention (IVDC)" (Tan et al. 2020: 61). ${ }^{1}$ COVID-19 is not the first coronavirus to make waves in the twenty-first century. Watching news media coverage, one could be forgiven for thinking that it is entirely new. However, it was preceded by MERS-CoV, the Middle East Respiratory Syndrome, cases of which were reported starting in 2012, and SARS-CoV, Severe Acute Respiratory Syndrome, which was first recognized in 2003.

Respiratory syndromes linked to coronavirus excite attention on the part of media and other organizational actors such as public health agencies because of a variety of factors, including their potential to spread rapidly through populations and become pandemic in scale, as well as their "severity" or their potential to produce life-threatening illness. Such viruses are assumed to come from an "animal reservoir," a feature that is said to make them particularly dangerous to humans because they are unknown to the human immune system (US CDC 2020a). The World Health Organization (WHO) characterized COVID-19 as a pandemic on 11 March 2019 (WHO 2020a). Prior to this, on 30 January 2020, WHO Director General Dr. Tedros Adhanom Ghebreyesus declared "a public health emergency of international concern of the global outbreak of novel coronavirus" (WHO 2020b). Defined in the revised International Health Regulations (IHR) (2005) - a document that was itself propelled into its twenty-first century iteration by SARS - the declaration of an emergency triggers a range of obligations on state parties, including provisions related to

\footnotetext{
${ }^{1}$ It is noteworthy that in the paper published by Huang and colleagues in The Lancet, the authors indicate that the process for obtaining consent to perform this viral identification was circumvented. As they report, "Written informed consent was waived by the Ethics Commission of the designated hospital for emerging infectious diseases" (Huang et al. 2020: 498). As scholars of surveillance well know, states of exception go hand in hand with the deployment of extraordinary control measures and practices designed to intensify the gaze (e.g., Aas 2011; Abujidi 2010; Bigo 2006; French 2007; Lyon 2003; Monahan and Murakami Wood 2018; Topak 2017; Wilson and Weber 2008).
} 
notification and information-sharing (WHO 2005). The declaration of an emergency also provides moral license to depart from business as usual, and indeed we have since seen many countries take drastic measures to contain the spread of COVID-19, including implementing travel bans and quarantines, as well as intensified surveillance in places like airports (e.g., Griffiths 2020).

These developments have been accompanied by an amplification in popular discourse - through broadcast and social media - of fear associated with pandemic disease, not to mention the rejuvenation of some of epidemiology's most stigmatizing and problematic concepts (e.g., "super-spreader"). We have also seen the emergence of travel bans that target specific countries and nationalities, alongside augmented racial profiling of presumed human vectors (e.g., Egan and Gregorian 2020; Seddon 2020). (The racist dimensions of this crisis are discussed in further detail below.)

Clearly, the entire global economy has now been thrown into a tailspin as all sectors grapple with containing the virus while managing its associated dangers and uncertainties. Manufacturing, distribution, tourism, education, and healthcare, along with other vital components of the economy, are in shock mode as they confront shortages and take precautionary measures to mitigate risk. In the wake of national emergency declarations, panic buying and price gouging, especially of staple consumer goods, are amplifying these instabilities. The ripple effect through tightly coupled industries is generating a rapid decline in the value of stocks, pushing the global economy to the brink of another recession and thrusting vulnerable workers further into economic precarity. While various interventions are expected from governments and international bodies, of especial note are massive state allocations for the production of vaccines. ${ }^{2}$ For instance, the USA's $\$ 8.3$ billion emergency spending package designates roughly $\$ 3$ billion for vaccine development, most of which will be directed toward the pharmaceutical industry (Hirsch and Breuninger 2020; Simmons-Duffin 2020). Even though the coronavirus may have petered out by the time the vaccines are approved for the market, advance purchase contracts will ensure that this articulation of "disaster capitalism" (Klein 2007) will fuel industry, perhaps ultimately to the detriment of other pressing health needs. ${ }^{3}$

In the US context, the absence of universal health care means that economic inequalities are exacerbated by the COVID-19 threat, punishing many sick and/or worried individuals and their families with crippling healthcare costs should they seek diagnosis or treatment (Hoffower 2020). Even in Canada, where health care and public health systems are, comparatively speaking, robust and universally accessible, years of austerity budgeting by provinces (Evans and Fanelli 2018) have now led to questions about whether these systems have the resiliency and capacity to deal with the surge of critically ill patients that COVID-19 could produce. The situation, in sum, is primed to aggravate extant health inequities (Ruckert and Labonté 2014). Indeed, the economic and health harms of this crisis are being - and will continue to be-felt unevenly.

\section{COVID-19 Surveillance: What is It?}

Amidst this crisis, one institutionalized response promises a modicum of certainty: surveillance. Daily counts of confirmed cases, along with a catalogue of the number of deaths related to COVID-19, work to provide authorities with a common ground for action. Yet, while providing a concrete accounting of

\footnotetext{
${ }^{2}$ New instantiations of "pharmaceutical nationalism" (Hayden 2015) are forming too, as can be seen with US attempts to lure German vaccine producer CureVac to the US so that US citizens could benefit first from any protections provided by eventual coronavirus vaccines (Carrel and Rinke 2020).

3 Andrew Lakoff (2015: 314) describes a similar situation with earlier vaccines for H1N1 in Europe, where once the vaccines were made available, they were deemed of little use, even after substantial state investment in them. As a result, "the governments of France, Germany, and England all sought to renegotiate their advance purchase agreements with vaccine manufacturers and to unload their excess doses on poor countries in the global south at bargain prices."
} 
prevalence and incidence, surveillance of COVID-19 also produces a range of uncertainties. These uncertainties start to come into view when we ask what, exactly, is surveillance of COVID-19?

Public health professionals and organizations typically have a specific domain of practice in mind when they use the term surveillance. Classically, they have tended to distinguish surveillance of disease from surveillance of individuals (e.g., Langmuir 1963; see also French 2009). The IHR defines surveillance as "the systematic ongoing collection, collation and analysis of data for public health purposes and the timely dissemination of public health information for assessment and public health response as necessary" (WHO 2005: 10). In this vein, WHO guidelines for the surveillance of COVID-19 outline the following objectives: "1) monitor trends in the disease where human-to-human transmission occurs; 2) rapidly detect new cases in countries where the virus is not circulating; 3) provide epidemiological information to conduct risk assessments at the national, regional and global levels; [and] 4) provide epidemiological information to guide preparedness and response measures" (WHO 2020c). The WHO guidelines also specify a set of "case definitions" of COVID-19, aiming to distinguish between "suspected cases," "probable cases," and "confirmed cases" (i.e., laboratory confirmed cases) (WHO 2020c). The organization provides recommendations for contact tracing (i.e., identifying people who have been in contact with someone identified as a case), laboratory testing, case-reporting to the WHO, data aggregation, and specimen collection (WHO 2020b).

\section{Surveillance Studies Perspectives}

Of course, from a surveillance studies perspective, this definition of disease surveillance and the WHO's guidelines for surveillance of COVID-19 leave unnamed a wide swath of practices implicated in the surveillance of presumptive coronavirus cases. Between the categories of the suspected, the probable, and the confirmed lies a mess of complex social reality. Surveillance studies scholarship can bring this mess into view by attending to the differences between logics (or guidelines) and practices (e.g., French 2014; Magnet 2011; Smith 2015), and there is a need to look beyond WHO guidelines to see how the surveillance of COVID-19 is actually happening in practice.

Not mentioned in the WHO's guidelines, for instance, is anything about how risk communication messages propagate through deeply surveillant media and social media networks. Also unnamed are countless instances of interpersonal surveillance of the kind embodied in side-long looks at - and evasion of - others who dare to sneeze, cough, or even walk too closely to others in shared spaces such as airports, mass transit, or cafes. And, in spite of all of the public health talk about monitoring one's self for symptoms of illness, this action is not contemplated as a form of surveillance in public health discourse.

Nevertheless, the surveillant dynamics of these modes of monitoring for COVID-19 may be reflected in established surveillance studies concepts like "lateral surveillance" (Andrejevic 2005), "participatory surveillance" (Albrechtslund 2008), "social surveillance" (Marwick 2012), "self-vigilance" (Koskela 2000; 2003), "self-tracking" (Lupton and Smith 2018), and "exposure" (Ball 2009). ${ }^{4}$ These concepts name processes and practices that have to do with social order and subjectivity-formation in everyday life. Even if their surveillant dynamics are not explicitly acknowledged in public health discussions of surveillance, they are given structural weight in public health recommendations to avoid close contact and to act responsibly. ${ }^{5}$

Accordingly, to better capture the range of surveillant dynamics at work in our consideration of COVID19 , it seems analytically necessary to shift to a broader understanding of surveillance than what is typically given in public health discourse. This understanding could productively contemplate "any tracking and monitoring, whether systematic or not, of health-related information," as well as any tracking and

\footnotetext{
${ }^{4}$ See Saulnier (2017) for a review of surveillance studies work on the surveilled subject.

${ }^{5}$ The US CDC suggests that people can protect themselves from COVID-19 by practicing hand hygiene and avoiding close contact with people. Its website, entitled How to Protect Yourself, lists steps like "Clean your hands often" and "Put distance between yourself and other people if COVID-19 is spreading in your community" (US CDC 2020b).
} 
monitoring that could be enrolled into the work of determining the health status of people and populations (French and Smith 2013: 383; see also, Armstrong 1995; Fisher and Monahan 2011).

\section{Dis-ease Surveillance}

A helpful text for locating the current public health response to COVID-19, and the specter of emerging infectious disease more generally, is Weir and Mykhalovskiy's (2010) Global Public Health Vigilance. This book traces the twenty-first century reconfiguration of infectious disease surveillance at national, regional, and global levels. As Weir and Mykhalovskiy argue, the form of public health reasoning that emerges in the twenty-first century has as a key goal the containment of "public health emergencies prior to their spread across international boundaries" (Weir and Mykhalovskiy 2010: 3, emphasis ours). This effort to interrupt disease transmission before it crosses international boundaries reflects

a broader set of time-space relations that are characteristic of contemporary thinking about pandemics. On the one hand, these relations involve a high degree of sensitivity to the spatial dimensions of health events, especially their potential to extend beyond local settings. On the other hand, they are beset by a deep anxiety about the timeliness of response, the outcome of which is an immense effort to detect, pre-empt or rapidly respond to health events to prevent them from having trans-local effects (French and Mykhalovskiy 2013: 175).

This effort to detect, pre-empt, and rapidly respond to health events like pandemics has effects that work to configure medical care and public health systems. We might consider, for example, what it means for publics to be constructed through the anticipatory measures sparked by pandemic anxiety (French and Mykhalovskiy 2013; Thomas 2014).

Pandemic anxiety creates dis-ease in several different registers, and these are worthy of scholarly attention. As noted above, it would be worthwhile to consider how COVID-19 is reconfiguring

1) cultural understandings of bodily vulnerability; 2) social processes of stigmatization and marginalization; 3) structural inequalities and forms of structural, everyday violence, which predispose people and communities to the harmful effects of communicable disease while also undercutting their capacity to respond to these effects; and 4) the role played by public health and other authorities in disease construction as well as the problems, unintended consequences and issues arising out of their efforts to detect, pre-empt and contain disease spread. (French et al. 2018: 67)

Surveillance studies scholarship might, in this sense, productively engage in the surveillance of dis-ease sparked by COVID-19.

\section{What Can Surveillance Studies Say?}

Following from recent trends in the field to problematize violent, racialized inflections of surveillance (e.g., Benjamin 2019; Browne 2015; Dubrofsky and Magnet 2015; Hall 2015), the global COVID-19 crisis is crying out for a critique of the categorization and demonization of racialized populations. In this case, politicians, fringe and mainstream media, and others have been quick to paint Chinese people as culpable for the origination and spread of the virus, as contagious embodiments of anxiety and risk unjustly visited upon "civilized" populations (Ellen 2020). As Marnie Ritchie (2020: 13) writes in this issue, the raced body is reduced "to an object of anxiety... a raced body is an unsettler of objects. The body becomes a moving target, a target because it can move. This body is accused of upending the capacity of those integrated into whiteness to feel settled in time and space." Although Ritchie is not writing about the coronavirus, per se, one can easily detect the pattern in how racialized others are perceived as destabilizing and threatening to the white body politic. In these ways, a cultural script of racial dehumanization and white victimization animates extreme surveillance measures and is used to justify augmented intervention through surveillance, 
containment, or attack (Monahan 2017). Particularly when there is a perceived existential threat, as with COVID-19, racial categories become incredibly slippery and capacious. Expansive understanding of racialized threat can be seen, for instance, with fearful whites physically assaulting "Asian-looking" individuals (Guy 2020; Yan et al. 2020) or with US President Trump calling COVID-19 a "foreign virus" (Liptak and Vazquez 2020), instituting travel bans for foreign nationals (but not US citizens) traveling from Europe (Egan and Gregorian 2020), and considering closing the US-Mexico border as a way to prevent the spread of the virus (Associated Press 2020). In these ways, the virus is conflated with racial threat and attached to deeper cultural narratives of racial contagion to the detriment of science-based public health interventions. ${ }^{6}$

What is especially fascinating about the COVID-19 crisis is how it has been able to short-circuit what were growing critiques of China's surveillance state, its social credit system, and its internment ("reeducation") camps for Uyghur Muslims and others (Matsakis 2019; Mitchell and Diamond 2018; Ramzy and Buckley 2019). The fact that the Chinese state has seemingly been able to arrest the spread of the virus by using some of the same heavy-handed techniques of surveillance-based control and containment has drawn praise from Western sources that might have previously denounced those tactics as abuses of human rights (Kuo 2020; Kupferschmidt and Cohen 2020). From a surveillance studies perspective, we might question the ways that this global health crisis is being used to normalize oppressive surveillance measures, perhaps making them seem more palatable or even necessary as insurance against unknown future contagions or threats. ${ }^{7}$ If surveillance is thought of as existing on a spectrum between care and control (Lyon 2001), then this case highlights how both care and control can look like oppression.

Given the technological nature of many of the proposed responses to this pandemic, surveillance figures prominently in these developments. For example, South Korea's response, which is being presented as a model for "democratic" countries (Parodi et al. 2020), foregrounds fine-grained locational data and social network analysis to track and target individuals for containment and treatment, completely sidelining any privacy concerns along the way:

This includes enforcing a law that grants the government wide authority to access data: CCTV footage, GPS tracking data from phones and cars, credit card transactions, immigration entry information, and other personal details of people confirmed to have an infectious disease. The authorities can then make some of this public, so anyone who may have been exposed can get themselves - or their friends and family memberstested. (Parodi et al. 2020)

In a different register, Google has been praised for its plans to develop a website to assist individuals with assessing their personal risk and need for testing or treatment (Bartz 2020). This "solution" will likely invite even further data-harvesting and -sharing. If this Google website follows current Centers for Disease Control and Prevention (CDC) guidelines, which emphasize international risk over "community spread," it will algorithmically encode xenophobic mappings that align risk with foreign bodies or places. These are technological developments that hide their politics in plain sight, as fear and danger blind individuals and institutions to alternative answers that might protect privacy better and resist the normalization of racialized threat.

A surveillance studies orientation, in conversation with work that has theorized the mediated nature of pandemics (e.g., Levina 2015; Opitz 2017), could also direct attention to the algorithmic protocols shaping

\footnotetext{
${ }^{6}$ See also Silva (2016) for a broader discussion of the capaciousness of racialized threat in the US context.

${ }^{7}$ Such an approach is not unique to the Chinese context, of course. In the early days of the COVID-19 outbreak, for instance, epidemiologists and public health experts contacted one of the authors asking for advice on how to use mobile phones to track affected individuals and their networks in order to expedite and make much more precise disease surveillance, as well as to quarantine exposed people. These aspirations, which are in keeping with Googlebased tracking systems, could similarly function as a Trojan horse: encouraging people to accept intrusive surveillance in the name of public health and safety, regardless of where such applications and data might eventually creep.
} 
audience exposure to social media content about the coronavirus, as well as to the polarizing effects of such social sorting. On one hand, there is the (now expected and commonplace) channeling of audiences into "filter bubbles" (Pariser 2011) where those who are inclined to view the threat through a racialized lens will be fed such content, whereas those who might see the threat as one of flagging public health systems will likewise find confirmation. On the other hand, amplification of such trends can lead to all-out panic as disinformation (e.g., conspiracy theories, science skepticism) fuels the kinds of fictional apocalyptic scenarios described in our introduction. This disinformation modality-of destructive inaccuracy masquerading as unassailable fact - is only aggravated by claims from leaders like President Trump, who has referred to the coronavirus crisis as a Democratic "hoax" (Global News 2020). As Mark Andrejevic (2013) has observed, the contemporary informational ecology is characterized by a form of populist postmodernism where trust in institutions is eroded, leaving no agreed upon mechanisms for adjudicating truth claims. In such a space, fear and xenophobia readily fill the vacuum left by institutional authority. ${ }^{8}$

Meanwhile, if people have lost faith in institutional authority, this will not protect them from the wrath of institutions if they are believed to have negligently contributed to the spread of COVID-19. Already, criminal charges are being pursued against the Christian sect contributing to the outbreak in South Korea (Seibt 2020), and authorities in Canada say they are not ruling out criminal law sanctions for "knowingly spreading COVID-19" (Bensadoun 2020). As we have seen with respect to HIV, a criminal justice response has been resurgent in the past decade (Mykhalovskiy 2011), suggesting the rise of an increasingly punitive approach to infectious disease (Hoppe 2018). In the case of HIV, this development has occurred without any evidence that a criminal justice response assists in HIV prevention (Mykhalovskiy 2015). In light of such developments, scholars should expect - and question the implications of - flows of health data into criminal justice systems (Spieldenner 2020).

Finally, the field of surveillance studies could further unpack the kinds of lateral and self-surveillance practices we described above. Particularly given the many media and public health directives to mitigate risk through personal hygiene practices and "social distancing," it is obvious that the COVID-19 threat is being plugged into well-established neoliberal constructions of responsible subjects as those who manage risks on their own and do not (or cannot) rely on states or institutions to ensure safety:

This insecurity subject anticipates risks and minimizes them through consumption, regulates exposure to potentially threatening Others through systems of fortification, believes that economic inequalities are natural and social exclusion justified, voluntarily sacrifices privacy and civil liberties on the altar of national security, and fully supports punitive state policies, whether against immigrants, criminals, terrorists, or the poor. (Monahan 2010: 2)

Emphatically, personal hygiene practices and social distancing are important mechanisms for minimizing exposure to and spread of COVID-19. At the same time, the responsibilization move can also subtly (and not-so-subtly) redirect blame for the crisis and its (mis)management to individuals and their families (e.g., Gagnon and Guta 2012; Guta et al. 2016; McClelland et al. 2019), diverting attention from severely underfunded and understaffed public health and social services institutions, which are institutions that are

\footnotetext{
8 As Alice Marwick and Rebecca Lewis (2017) relate, distrust in the media and increased radicalization (e.g., ethnonationalism) are two of the outcomes of online disinformation. Distrust in state institutions occurs as well. Caught in a downward spiral, reduced financial and political support for public institutions can lead to failures, which then can be used to justify future reductions. As a troubling articulation of this trend, the United States' COVID-19 response has apparently been hampered by Trump administration funding cuts to the CDC and a longstanding unfilled position of "senior director for global health security and biothreats" (Borger 2020).
} 
critical for minimizing the death toll as countries contend with affected individuals. ${ }^{9}$ The insecurity subject, especially in the US context, also harmonizes disturbingly well with conservative anti-government "prepper" communities, which hoard supplies and weapons in anticipation of societal and/or environmental collapse (Foster 2014). Not surprisingly, racism infuses many elements of this prepper contingent, thereby solidifying destructive cultural divisions and encouraging the close monitoring and exclusion of - if not outright violence against—minoritized others (Watts 2017).

\section{Conclusion}

As the coronavirus spreads throughout the world, there are many unknowns that make writing such an editorial difficult. We are writing in the middle of a crisis and without the benefit of hindsight. We are hyperaware of the fact that this is a terrifying event, that people are dying, that fear is permeating people's lives. Yet, we, as surveillance studies scholars, are being called upon to speak to this crisis, and there are points we can raise and questions we can ask. In the words of anthropologist Kim Fortun (2001: 18), who was writing about the Bhopal chemical disaster, the situation is "too complex to fully understand, yet calls for a response." While we do not know how this situation will unfold or resolve, we do have insight into how it fits within existing patterns and relations, particularly those pertaining to sociocultural constructions of (in)security, vulnerability, and risk. We can see evidence of surveillance dynamics at play with how bodies and pathogens are being measured, tracked, predicted, and regulated. We can grasp how threat is being racialized, how and why institutions are flailing, and how social media might be fueling social divisions. There is, in other words, a lot that our scholarly community could add to the conversation. Doing so could alter collective understandings of the processes we critique here and possibly inflect diseasesurveillance policies or programs.

\section{References}

Aas, Katja Franko. 2011. "Crimmigrant” Bodies and Bona Fide Travelers: Surveillance, Citizenship and Global Governance. Theoretical Criminology 15 (3): 331-346

Abujidi, Nurhan. 2010. Surveillance and Spatial Flows in the Occupied Palestinian Territories. In Surveillance and Control in Israel/Palestine, Edited by E. Zureik, D. Lyon, and Y. Abu-Laban, 313-334. London: Routledge.

Albrechtslund, Anders. 2008. Online Social Networking as Participatory Surveillance. First Monday 13 (3). Available from http://firstmonday.org/htbin/cgiwrap/bin/ojs/index.php/fm/article/viewArticle/2142/1949 [accessed December 26, 2010 ].

Andrejevic, Mark. 2005. The Work of Watching One Another: Lateral Surveillance, Risk, and Governance. Surveillance \& Society 2 (4): 479-497.

2013. Infoglut: How Too Much Information is Changing the Way We Think and Know. New York: Routledge.

Armstrong, David. 1995. The Rise of Surveillance Medicine. Sociology of Health \& Illness 17 (3): 393-404.

Associated Press. 2020. Trump Says He is "Thinking About" Possibly Closing US Border with Mexico to Guard Against COVID19 Spread. WAOW.com, February 29. Available from https://waow.com/2020/02/29/trump-says-he-is-thinking-aboutpossibly-closing-us-border-with-mexico-to-guard-against-covid-19-spread/ [accessed March 11, 2020].

Ball, Kirstie S. 2009. Exposure: Exploring the Subject of Surveillance. Information, Communication \& Society 12 (5): 639-657.

Bartz, Diane. 2020. Google Says It is Developing a Nationwide Coronavirus Website. Reuters, March 14. Available from https:/www.reuters.com/article/us-health-coronavirus-google/google-says-it-is-developing-a-nationwide-coronaviruswebsite-idUSKBN212024 [accessed March 15, 2020].

Benjamin, Ruha. 2019. Race After Technology: Abolitionist Tools for the New Jim Code. Medford, MA: Polity Press.

Bensadoun, Emerald. 2020. Coronavirus: Can You Be Held Criminally Liable for Spreading It? Here's What the Law Says. Global News, March 10. Available from https://globalnews.ca/news/6654692/criminal-liability-coronavirus-canada/ [accessed March 15, 2020].

Bigo, Didier. 2006. Security, Exception, Ban and Surveillance. In Theorizing Surveillance: The Panopticon and Beyond, edited by D. Lyon, 46-68. Cullompton, UK: Willan.

9 Symptomatic of this individualized orientation to governance, leaders have repeatedly emphasized that people should stay home if they are not feeling well. But what about those who do not have homes? Evidently, they have been an afterthought in pandemic planning. In Montreal, for example, homeless shelters "are scrambling to keep operations running as an expected volunteer shortage looms" (Olson 2020). As people are instructed to stay home to combat COVID-19, the concern is that "upper levels of government have been focused on schools, events, public transit and municipal buildings while neglecting one of the province's most vulnerable populations" (Olson 2020). 
Borger, Julian. 2020. US Underprepared for Coronavirus Due to Trump Cuts, Say Health Experts. The Guardian, January 31. Available from https://www.theguardian.com/world/2020/jan/31/us-coronavirus-budget-cuts-trump-underprepared [accessed March 11, 2020].

Browne, Simone. 2015. Dark Matters: On the Surveillance of Blackness. Durham, NC: Duke University Press.

Carrel, Paul, and Andreas Rinke. 2020. Germany Tries to Stop U.S. from Luring Away Firm Seeking Coronavirus Vaccine. Reuters, March 15. Available from https://www.reuters.com/article/us-health-coronavirus-germany-usa/germany-tries-to-stop-us-from-luring-away-firm-seeking-coronavirus-vaccine-idUSKBN2120IV [accessed March 15, 2020].

Dubrofsky, Rachel E., and Shoshana Amielle Magnet, eds. 2015. Feminist Surveillance Studies. Durham, NC: Duke University Press.

Egan, Lauren, and Dareh Gregorian. 2020. Coronavirus: Trump Restricts Travel from Most of Europe by Foreigners. NBCNEWS.com, March 11. Available from https://www.nbcnews.com/politics/donald-trump/trump-make-prime-timeaddress-coronavirus-wednesday-night-n1155941 [accessed March 15, 2020].

Ellen. 2020. John Oliver Magnificently Shreds Trump and Fox Economist Playing Coronavirus Expert On TV. NewsHounds, March 2. Available from

http://www.newshounds.us/john_oliver_shreds_trump_fox_economist_playing_coronavirus_expert_030220 [accessed March 11, 2020].

Evans, Bryan, and Carlo Fanelli. 2018. The Public Sector in an Age of Austerity: Perspectives from Canada's Provinces and Territories. Montreal \& Kingston: McGill-Queen's University Press.

Fisher, Jill A., and Torin Monahan. 2011. The "Biosecuritization" of Healthcare Delivery: Examples of Post-9/11 Technological Imperatives. Social Science and Medicine 72 (4): 545-552.

Fortun, Kim. 2001. Advocacy after Bhopal: Environmentalism, Disaster, New Global Orders. Chicago: University of Chicago Press.

Foster, Gwendolyn Audrey. 2014. Hoarders, Doomsday Preppers, and the Culture of Apocalypse. New York: Springer.

French, Martin. 2007. In the Shadow of Canada's Camps. Social \& Legal Studies 16 (1): 49-69.

. 2009. Woven of War-Time Fabrics: The Globalization of Public Health Surveillance. Surveillance \& Society 6 (2): $101-$ 115.

2014. Gaps in the Gaze: Informatic Practice and the Work of Public Health Surveillance. Surveillance \& Society 12 (2): 226-243.

French, Martin, and Eric Mykhalovskiy. 2013. Public Health Intelligence and the Detection of Potential Pandemics. Sociology of Health \& Illness 35 (2): 174-187.

French, Martin, and Gavin JD Smith. 2013. Health Surveillance and Everyday Life-Special Section. Critical Public Health 23 (4): $383-431$.

French, Martin, Eric Mykhalovskiy, and Carmen Lamothe. 2018. Epidemics, Pandemics and Outbreaks. In A. Javier Treviño (ed), The Cambridge Handbook of Social Problems, 59-77. Cambridge: Cambridge University Press.

Gagnon, Marilou, and Adrian Guta. 2012. Mapping HIV Community Viral Load: Space, Power and the Government of Bodies. Critical Public Health 22 (4): 471-483.

Global News. 2020. Donald Trump Holds "Keep America Great" Rally in Charleston, S.C. YouTube, February 28. Available from https://www.youtube.com/watch?v=NbwCjL7HC1c [accessed March 11, 2020].

Griffiths, James, and Amy Woodyatt. 2020. China Goes into Emergency Mode as Number of Confirmed Wuhan Coronavirus Cases Reaches 2,700. CNN, https:/www.cnn.com/2020/01/26/asia/wuhan-coronavirus-update-intl-hnk/index.html [accessed March 16, 2020].

Guta, Adrian, Stuart Murray, and Marilou Gagnon. 2016. HIV, Viral Suppression and New Technologies of Surveillance and Control. Body \& Society 22 (2): 82-107.

Guy, Jack. 2020. East Asian Student Assaulted in "Racist" Coronavirus Attack in London. CNN.com, March 3. Available from https://www.cnn.com/2020/03/03/uk/coronavirus-assault-student-london-scli-intl-gbr/index.html [accessed March 11, 2020].

Hall, Rachel. 2015. The Transparent Traveler: The Performance and Culture of Airport Security. Durham, NC: Duke University Press.

Hayden, Cori. 2015. Generic Medicines and the Question of the Similar. In The Pharmaceutical Studies Reader, edited by S. Sismondo and J. A. Greene, 261-267. Malden, MA: Wiley Blackwell.

Hirsch, Lauren, and Kevin Breuninger. 2020. Trump signs \$8.3 Billion Emergency Coronavirus Spending Package. CNBC.com, March 6. Available from https://www.cnbc.com/2020/03/06/trump-signs-8point3-billion-emergency-coronavirusspending-package.html [accessed March 11, 2020].

Hoffower, Hillary. 2020. A US Resident Racked up a \$3,200 Hospital Bill for Suspected Coronavirus Treatment, and His Insurance Only Covered Part of It. Here's How the Costs Broke Down. Business Insider, March 3. Available from https://www.businessinsider.com/coronavirus-treatment-medical-bill-hospital-costs-2020-3 [accessed March 11, 2020].

Hoppe, Trevor. 2018. Punishing Disease: HIV and the Criminalization of Sickness. Oakland: University of California Press.

Huang, Chaolin, Yeming Wang, Xingwang Li, Lili Ren, Jianping Zhao, Yi Hu, Li Zhang, Guohui Fan, Jiuyang Xu, Xiaoying Gu, Zhenshun Cheng, Ting Yu, Jiaan Xia, Yuan Wei, Wenjuan Wu, Xuelei Xie, Wen Yin, Hui Li, Min Liu, Yan Xiao, Hong Gao, Li Guo, Jungang Xie, Guangfa Wang, Rongmeng Jiang, Zhancheng Gao, Qi Jin, Jianwei Wang, and Bin Cao. 2020. Clinical Features of Patients Infected with 2019 Novel Coronavirus in Wuhan, China. The Lancet 395 (10223): $497-506$.

Koskela, Hille. 2000. "The Gaze without Eyes": Video-Surveillance and the Changing Nature of Urban Space. Progress in Human Geography 24 (2): 243-265.

. 2003. "Cam Era"-The Contemporary Urban Panopticon. Surveillance \& Society 1 (3): 292-313.

Klein, Naomi. 2007. The Shock Doctrine: The Rise of Disaster Capitalism. New York: Metropolitan Books. 
Kuo, Lily. 2020. How did China Get to Grips with its Coronavirus Outbreak? The Guardian, March 9. Available from https://www.theguardian.com/world/2020/mar/09/how-did-china-get-grips-with-coronavirus-outbreak [accessed March 11, 2020].

Kupferschmidt, Kai, and Jon Cohen. 2020. China's Aggressive Measures Have Slowed the Coronavirus. They May Not Work in Other Countries. Science, March 2. Available from https://www.sciencemag.org/news/2020/03/china-s-aggressivemeasures-have-slowed-coronavirus-they-may-not-work-other-countries [accessed March 11, 2020].

Lakoff, Andrew. 2015. Global Health Security and the Pathogenic Imaginary. In Dreamscapes of Modernity: Sociotechnical Imaginaries and the Fabrication of Power, edited by S. Jasanoff and S.-H. Kim, 300-320. Chicago: University of Chicago Press.

Langmuir, Alexander. 1963. The Surveillance of Communicable Diseases of National Importance. The New England Journal of Medicine 268 (4): 182-192.

Levina, Marina. 2015. Pandemics and the Media. New York: Peter Lang.

Liptak, Kevin, and Maegan Vazquez. 2020. Trump Says He's Suspending Travel from Europe to US, though Citizens and Others are Exempt. CNN.com, March 12. Available from https://www.cnn.com/2020/03/11/politics/donald-trump-coronavirusstatement/index.html [accessed March 15, 2020].

Lupton, Deborah, and Gavin JD Smith. 2018. "A Much Better Person": The Agential Capacities of Self-Tracking Practices. In Metric Culture: Ontologies of Self-Tracking Practices, edited by B. Ajana, 57-75. London: Emerald.

Lyon, David. 2001. Surveillance Society: Monitoring Everyday Life. Buckingham, England: Open University. 2003. Surveillance After September 11. Cambridge, MA: Polity.

Magnet, Shoshana Amielle. 2011. When Biometrics Fail: Gender, Race, and the Technology of Identity. Durham, NC: Duke University Press.

Marwick, Alice. 2012. The Public Domain: Surveillance in Everyday Life. Surveillance \& Society 9 (4): $378-93$.

Marwick, Alice, and Rebecca Lewis. 2017. Media Manipulation and Disinformation Online. New York: Data \& Society Research Institute.

Matsakis, Louise. 2019. How the West Got China's Social Credit System Wrong. Wired, July 29. Available from https://www.wired.com/story/china-social-credit-score-system/ [accessed March 11, 2020].

McClelland, Alexander, Adrian Guta, and Marilou Gagnon. 2019. The Rise of Molecular Surveillance: Implications on Consent and Criminalization. Critical Public Health, https://www.tandfonline.com/doi/abs/10.1080/09581596.2019.1582755.

Mitchell, Anna, and Larry Diamond. 2018. China's Surveillance State Should Scare Everyone. The Atlantic, February 2. Available from https://www.theatlantic.com/international/archive/2018/02/china-surveillance/552203/ [accessed March 11, 2020].

Monahan, Torin. 2010. Surveillance in the Time of Insecurity. New Brunswick, NJ: Rutgers University Press.

- 2017. Regulating Belonging: Surveillance, Inequality, and the Cultural Production of Abjection. Journal of Cultural Economy 10 (2): 191-206.

Monahan, Torin, and David Murakami Wood, eds. 2018. Surveillance Studies: A Reader. New York: Oxford University Press.

Mykhalovskiy, Eric. 2011. The Problem of "Significant Risk": Exploring the Public Health Impact of Criminalizing HIV NonDisclosure. Social Science \& Medicine 73 (5): 668-675.

2015. The Public Health Implications of HIV Criminalization: Past, Current, and Future Research Directions. Critical Public Health 25 (4): 373-385

Olson, Isaac. 2020. Food Banks, Shelters Race to Protect Montrealers Living in Poverty from COVID-19. CBC News, March 14. Available from https://www.cbc.ca/news/canada/montreal/covid-19-homeless-food-banks-montreal-1.5497771 [accessed March 15, 2020].

Opitz, Sven. 2017. Simulating the World: The Digital Enactment of Pandemics as a Mode of Global Self-Observation. European Journal of Social Theory 20 (3): 392-416.

Oxford English Dictionary. 1998. The New Oxford Dictionary of English. Edited by J. Pearsall and P. Hanks. Oxford: Oxford University Press.

Pariser, Eli 2011. How the Net Traps Us All in Our Own Little Bubbles. The Guardian, June 12. Available from http://www.guardian.co.uk/technology/2011/jun/12/google-personalisation-internet-datafiltering?cat=technology\&type $=$ article [accessed June 15, 2011].

Parodi, Emilio, Stephen Jewkes, Sangmi Cha, and Ju-min Park. 2020. Special Report: Italy and South Korea Virus Outbreaks Reveal Disparity in Deaths and Tactics. Reuters, https://www.reuters.com/article/us-health-coronavirus-responsespecialre/special-report-italy-and-south-korea-virus-outbreaks-reveal-disparity-in-deaths-and-tactics-idUSKBN20Z27P [accessed March 15, 2020].

Ramzy, Austin, and Chris Buckley. 2019. Leaked China Files Show Internment Camps Are Ruled by Secrecy and Spying. New York Times, November 24. Available from https://www.nytimes.com/2019/11/24/world/asia/leak-chinas-internmentcamps.html [accessed March 11, 2020].

Ritchie, Marnie. 2020. Fusing Race: The Phobogenics of Racializing Surveillance. Surveillance \& Society 18 (1): $12-29$.

Ruckert, Arne, and Ronald Labonté. 2014. The Global Financial Crisis and Health Equity: Early Experiences from Canada. Globalization and Health 10 (1), http://www.globalizationandhealth.com/content/10/1/2.

Saulnier, Alana. 2017. Surveillance as Communicating Relational Messages: Advancing Understandings of the Surveilled Subject. Surveillance \& Society 15 (2): 286-302.

Seddon, Max. 2020. Russia Bans Flights to Korea, Warns Against Travel to Italy, Financial Times, https://www.ft.com/content/ac625338-6f2c-359e-933c-b0457b572fa1 [accessed March 15, 2020].

Seibt, Sébastian. 2020. South Korea Seeks Criminal Charges against Christian Sect over Coronavirus Spread. France24, March 3. Available from https://www.france24.com/en/20200303-south-korea-seeks-criminal-charges-against-christian-sect-overcoronavirus-spread [accessed March 16, 2020]. 
Silva, Kumarini. 2016. Brown Threat: Identification in the Security State. Minneapolis: University of Minnesota Press.

Simmons-Duffin, Selena. 2020. Where That \$8.3 Billion in U.S. Coronavirus Funding Will and Won’t Go. NPR, March 6. Available from https://www.npr.org/sections/health-shots/2020/03/06/812964894/where-that-8-3-billion-in-u-s-coronavirusfunding-will-and-wont-go [accessed March 11, 2020].

Smith, Gavin JD. 2015. Opening the Black Box: The Work of Watching. London: Routledge.

Spieldenner, Andrew. 2020. Who Counts? Some Thoughts on HIV Surveillance. POZ, https://www.poz.com/blog/counts [accessed March 15, 2020].

Thomas, Lindsay. 2014. Pandemics of the Future: Disease Surveillance in Real Time. Surveillance \& Society 12 (2): $287-200$.

Topak, Özgün. 2017. The Making of a Totalitarian Surveillance Machine: Surveillance in Turkey Under AKP Rule. Surveillance \& Society 15 (3/4): 535-542.

United States Centers for Disease Control and Prevention (US CDC). 2020a. Coronavirus Disease 2019 (COVID-19) Situation Summary. Atlanta: US CDC, https://www.cdc.gov/coronavirus/2019-ncov/summary.html [accessed March 14, 2020].

United States Centers for Disease Control and Prevention (US CDC). 2020b. Coronavirus Disease 2019 (COVID-19) - How to Protect Yourself. Atlanta, US CDC, https:/www.cdc.gov/coronavirus/2019-ncov/prepare/prevention.html [accessed March 14, 2020].

Watts, Eric King. 2017. Postracial Fantasies, Blackness, and Zombies. Communication and Critical/Cultural Studies 14 (4): $317-$ 333

Wenjie Tan, Xiang Zhao, Xuejun Ma, Wenling Wang, Peihua Niu, Wenbo Xu, George Gao, and Buizhen Wu. 2020. A Novel Coronavirus Genome Identified in a Cluster of Pneumonia Cases-Wuhan, China 2019-2020, China CDC Weekly 2 (4): 61-62.

Wilson, Dean, and Leanne Weber. 2008. Surveillance, Risk and Preemption on the Australian Border. Surveillance \& Society 5 (2): $124-141$.

World Health Organization (WHO). 2005. International Health Regulations, 3rd Edition. Geneva: WHO, https://www.who.int/ihr/publications/9789241580496/en/ [accessed March 14, 2020].

World Health Organization (WHO). 2020a. WHO Director-General's Opening Remarks at the Media Briefing on COVID-19-11 March 2020, WHO Director General, Speeches. Geneva: WHO: https://www.who.int/dg/speeches/detail/who-directorgeneral-s-opening-remarks-at-the-media-briefing-on-covid-19---11-march-2020 [accessed March 14, 2020 ].

World Health Organization (WHO). 2020b. WHO Director-General's Statement on IHR Emergency Committee on Novel Coronavirus (2019-nCoV), WHO Director General, Speeches. Geneva: WHO, https://www.who.int/dg/speeches/detail/who-director-general-s-statement-on-ihr-emergency-committee-on-novelcoronavirus-(2019-ncov) [accessed March 14, 2020].

World Health Organization (WHO). 2020c. Global Surveillance for Human Infection with Coronavirus Disease (COVID-19). Geneva: WHO, https://www.who.int/publications-detail/global-surveillance-for-human-infection-with-novelcoronavirus-(2019-ncov) [accessed March 14, 2020].

Yan, Holly, Natasha Chen, and Dushyant Naresh. 2020. What's Spreading Faster than Coronavirus in the US? Racist Assaults and Ignorant Attacks against Asians. CNN.com, February 21. Available from https://www.cnn.com/2020/02/20/us/coronavirus-racist-attacks-against-asian-americans/index.html [accessed March 11, 2020]. 